\title{
Profil Histopatologik Adenokarsinoma Prostat di Laboratorium Patologi Anatomik Sumatera Barat Tahun 2015-2017
}

Ria Oktavia ${ }^{1}$, Yenita $^{2}$

\begin{abstract}
Abstrak
Adenokarsinoma prostat merupakan keganasan kedua terbanyak pada laki-laki dan menjadi penyebab kematian kelima akibat keganasan pada laki-laki di dunia. Tujuan: Mengetahui profil histopatologik adenokarsinoma prostat berdasarkan kelompok usia, grade-group, derajat histopatologik dan invasi perineural. Metode: Penelitian ini merupakan studi deskriptif terhadap 106 kasus adenokarsinoma prostat di lima laboratorium Patologi Anatomi di Sumatera Barat periode Januari 2015 sampai Desember 2017. Sampel diperoleh dari blok parafin jaringan hasil operasi Transuretral Resection of Prostat (TURP) dan prostatektomi, kemudian dilakukan reevaluasi terhadap derajat histopatologik dan invasi perineura berdasarkan ISUP 2014/WHO 2016. Hasil: Kasus adenokarsinoma prostat paling banyak ditemukan pada kelompok usia 70-80 tahun. Grade-group tersering adalah grade group 5 (51,89\%) dan semua grade-group paling banyak pada kelompok umur 71-80 tahun, derajat histopatologis terbanyak yaitu poorly differentiated $(66,04 \%)$, invasi perineural ditemukan pada 31 kasus $(29,24 \%)$ dan paling banyak ditemukan pada grade group 5. Simpulan: adenokarsinoma prostat paling banyak ditemukan pada usia tua dengan grade-group yang tinggi dan derajat histopatologik yang buruk. Invasi perineural hanya ditemukan pada sepertiga kasus namun invasi perineural positif paling banyak ditemukan grade group 5 .
\end{abstract}

Kata kunci: adenokarsinoma prostat, derajat histopatologik, skor gleason, invasi perineural

\section{Abstract}

Prostatic adenocarsinoma is the second most common malignancy and the fifth leading death among men in the world. Objectives: To evaluated profile of prostat adenocainoma based on age, grade group, histopatological grade and perineural invasion. Methods: This research was a descriptive study with 106 cases of prostat carcinoma that were diagnosed in 5 Pathology Anatomy Laboratory in West Sumatera from January 2015 until Desember 2017. Samples were obtained from parafin block of tissue surgery from transuretral resection of prostat (TURP) dan prostatectomy and were reevaluated for histopathological grade and perineural invasion based on ISUP 2014/WHO 2016. Results: The mayority of case found in 70-80 years old, grade group that mostly found is grade group 5, poorly differentiated cases were mostly found (66,04\%). Perineural invasion were found in 31 case, mostly in grade group 5. Conclusion: prostate adenocarcinoma mostly found in elderly age with high grade group and poorly histopathological grade. Perineural invasion only found in onethird cases but perineural invasion mostly found in grade group 5.

Keywords: prostate adenocarcinoma, histopatological grade, gleason score, perineural invasion

Affiliasi penulis: 1. RSUD Mohammad Natsir, Solok 2. Bagian Patologi Anatomi, Fakultas Kedokteran, Universitas Andalas, Padang, Indonesia.

Korespondensi: Yenita, Email: yenita@med.unand.ac.id Telp: 082169523833

\section{Pendahuluan}

Karsinoma prostat merupakan keganasan kedua terbanyak pada laki-laki di dunia setelah kanker paru dan menjadi penyebab kematian kelima dengan angka kematian hampir 307.500 kasus. ${ }^{1}$ Insiden 
tertinggi ditemukan di Amerika utara, Karibia, Brazil, Eropa Barat, Australia dan New Zealand, sedangkan insiden terendah terjadi di Asia, beberapa negara Timur Tengah, dan Afrika. $^{2}$ Karsinoma prostat merupakan keganasan keenam terbanyak di Asia dengan angka kematian rata-rata 3,8 per 100.000 penduduk. $^{3}$ Berdasarkan data histopatologik Badan Registrasi Kanker Ikatan Ahli Patologi Anatomi Indonesia (BRKIAPI) dan Departemen Kesehatan RI tahun 2014, adenokarsinoma prostat merupakan keganasan keempat terbanyak dari 10 tumor ganas primer terbanyak pada laki-laki di Indonesia, sedangkan di Sumatera Barat, karsinoma prostat menduduki urutan kedua dari 10 tumor ganas primer tersering pada laki-laki setelah karsinoma kolorektal. ${ }^{4}$

Beberapa faktor risiko yang berhubungan dengan karsinoma prostat diantaranya usia, ras, riwayat keluarga, diet, hormonal faktor lingkungan, dan infeksi. ${ }^{3}$ Salah satu faktor risiko terbesar adalah usia. Karsinoma prostat merupakan keganasan terbanyak pada laki-laki usia tua. Angka kejadian dan kematian akibat karsinoma prostat ini meningkat seiring peningkatan usia. ${ }^{2.3}$ Lebih $75 \%$ kasus ditemukan pada usia > 65 tahun dan hanya $1 \%$ yang terdeteksi dibawah usia 50 tahun. Karsinoma prostat merupakan penyebab kematian kedua akibat kanker pada laki-laki usia 60-79 tahun. $^{2}$

Sistem Gleason merupakan sistem grading karsinoma prostat yang pertama kali diperkenalkan oleh Dr. Donal Gleason tahun 1966 dan telah digunakan secara luas di dunia. Grading ini dinilai berdasarkan pola/arsitektur kelenjar yang terdapat pada pemeriksaan mikroskopis dan diklasifikasikan menjadi lima grade. ${ }^{5}$

Perubahan atau modifikasi terhadap Gleason score yang asli pertama kali tahun 2005, kemudian dimodifikasi kembali oleh International Society of Urological Pathology (ISUP) pada tahun 2014. Perubahan ini diharapkan dapat meningkatkan reproduksibilitas dan nilai prognostik pada karsinoma prostat. ISUP telah merekomendasikan pelaporan karsinoma prostat dengan grade group yang dihubungkan dengan modifikasi Gleason score. Grade group diklasifikasikan menjadi 1-5. Berdasarkan studi multi-institusional dari 20.845 kasus karsinoma prostat, grade-group ini dinilai lebih merefleksikan prognosis dan menunjukkan faktor prediktif kuat dalam menilai progresi penyakit. ${ }^{6}$

Grade-group menunjukkan kurva prognosis yang sama pada laki-laki yang diterapi radiasi, hormonal atau radikal prostatektomi. Pada pengelompokan dengan grade group ini, jumlah Gleason score 7 telah dipisahkan menjadi grade group 2 (Gleason score 3+4) dan grade group 3 (Gleason score 4+3). ${ }^{6}$ Banyak studi melaporkan pada karsinoma prostat dengan pola kribriform yang dominan (Gleason score 4) berhubungan dengan tingginya rekurensi, ekstensi ekstraprostatika dan metastasis jauh sehingga menyebabkan perbedaan prognosis antara grade-group 2 dan grade-group 3.,6 Sistem grading terbaru ini telah diadopsi oleh WHO tahun $2016{ }^{2}$

Berdasarkan klasifikasi WHO 2016, derajat histopatologik karsinoma prostat juga dikelompokkan berdasarkan nilai Gleason score. ${ }^{2}$ Grade-group dan derajat histopatologik merupakan faktor prognosis yang penting pada karsinoma prostat dalam menilai progresi penyakit. Chen et al melaporkan pada studi kolaboratif pada beberapa negara di Asia, Indonesia merupakan negara terbanyak dengan kasus adenokarsinoma prostat dengan Gleason score tinggi (Gleason score >7) yaitu sekitar $70 \%$ dan juga merupakan negara tertinggi angka kejadian metastasisnya yaitu sekitar $40-50 \% .^{3}$ Faktor lain yang juga signifikan dalam menilai progresi karsinoma prostat adalah invasi perineural. Invasi perineural berhubungan dengan ekstensi ekstraprostatika sekitar 17-75\%. ${ }^{7}$ Pada pemeriksaan mikroskopis tampak selsel tumor menginfiltrasi atau mengelilingi sel saraf. Beberapa studi menunjukkan penemuan ini secara tidak langsung memprediksi metastasis dan rekurensi. 7,8 Penelitian Saeter et al di Norwegia menunjukkan hampir separuh (52\%) kasus invasi perineural terjadi pada Gleason score $\geq 8$. $^{9}$

\section{METODE}

Penelitian ini merupakan studi deskriptif observasional. Populasi adalah semua kasus adenokarsinoma prostat yang telah didiagnosis secara histopatologik di laboratorium Patologi Anatomi di Sumatera Barat yaitu Sentra Diagnostik Fakultas Kedokteran Universitas Andalas, RSUP M. Djamil Padang, RSI Ibnu Sina, RSI Siti Rahmah Padang, 
RSU Ahmad Muchtar Bukittinggi periode Januari 2015 sampai Desember 2017. Sampel penelitian adalah semua populasi yang sudah memenuhi kriteria inklusi dan eksklusi. Kriteria inklusi adalah kasus adenokarsinoma prostat yang mempunyai data lengkap, slaid dan blok parafin. Kriteria eksklusi adalah kasus adenokarsinoma prostat yang tidak dapat dilakukan reevaluasi terkait kondisi slaid HE dan blok parafinnya, rusak/tidak ditemukan.

Data primer pada penelitian ini adalah hasil reevaluasi slaid secara mikroskopis dengan menggunakan modifikasi Gleason score berdasarkan ISUP 2014/WHO 2016 kemudian dikelompokkan ke dalam grade grup dan derajat histopatologik yang telah ditetapkan. Pada penelitian ini juga dilakukan Penilaian terhadap invasi perineural. Apabila slaid tidak ditemukan maka dilakukan pemotongan ulang blok parafin dan pembuatan ulang slaid HematoksilinEosin (HE). Data sekunder adalah usia yang tercatat pada lembaran status pasien dan dikelompokkan dalam interval tertentu.

Grade-group dikelompokkan berdasarkan modifikasi Gleason score oleh ISUP 2014/WHO2016 yaitu grade group 1 (Gleason score $\leq 6)$, grade-group 2 (Gleason score 3+4), grade-group 3 (Gleason score $4+3)$, grade-group 4 (Gleason score 4+4), grade-group 5 (Gleason score > 9). ${ }^{2}$ Derajat histopatologik adenokarsinoma prostat dikelompokkan berdasarkan Klasifikasi WHO 2016 yaitu well differentiated (Gleason Score $\geq 6$ ), moderately differentiated (Gleason score 7), poorly differentiated (Gleason score $\geq 8)$. $^{2}$

\section{HASIL}

Pada penelitian ini diperoleh populasi sebanyak 115 kasus adenokarsinoma prostat di 5 laboratorium Patologi Anatomi di Sumatera Barat periode Januari 2015 sampai Desember 2017. Sembilan kasus dieksklusi karena sediaan HE dan blok parafin yang rusak atau tidak ditemukan. Sampel yang memenuhi kriteria inklusi dan eksklusi pada penelitian sebanyak 106 kasus, yang terdiri atas 84 kasus berasal dari tindakan transurethral resection of prostate (TURP) dan 22 kasus dari prostatektomi. Penilaian hasil penelitian dan reevaluasi slaid dilakukan oleh penulis dan didampingi oleh ahli patologi anatomi.

Tabel 1. Karakteristik adenokarsinoma prostat

\begin{tabular}{llr}
\hline Karakteristik & $\mathbf{f ( \mathbf { n } = \mathbf { 1 0 6 } )}$ & $\%$ \\
\hline $\begin{array}{l}\text { Umur (tahun) } \\
<51 \quad \text { tahun }\end{array}$ & 2 & 1,89 \\
$0 \quad$ tahun & 17 & 16,04 \\
$0 \quad$ tahun & 35 & 33,02 \\
$71-80$ tahun & 42 & 39,62 \\
$>80 \quad$ tahun & 10 & 9,43 \\
Grade group & & \\
1 (Gleason score $\leq 6)$ & 11 & 10,38 \\
2 (Gleason score 3+4) & 15 & 14,15 \\
3 (Gleason score 4+3) & 10 & 9,43 \\
4 (Gleason score 4+4) & 15 & 14,15 \\
5 (Gleason score $\geq 9)$ & 55 & 51,89 \\
Derajat Histopatologik & & \\
Well Differentiated & 11 & 10,38 \\
Moderately Differentiated & 25 & 23,58 \\
Poorly Differentiated & 70 & 66,04 \\
Invasi Perineural & & \\
Positif & 31 & 29,24 \\
Negatif & 75 & 70,75 \\
\hline
\end{tabular}

Tabel 1 menunjukkan kelompok umur terbanyak adalah umur 71-80 tahun yaitu sebanyak 42 kasus (39,62\%). Kelompok umur paling sedikit adalah umur $<51$ tahun yaitu 2 kasus $(1,89 \%)$. Grade-group yang terbanyak adalah grade-group 5 (Gleason score $\geq 9-10$ ) yaitu sebanyak 55 kasus (51, 89\%). Derajat histopatologis yang paling banyak dijumpai adalah poorly differentiated (Gleason score 810) dengan jumlah 70 kasus $(66,04 \%)$ dan yang paling sedikit yaitu well differentiated yaitu 11 kasus (10, $38 \%$ ). Kasus adenokarsinoma prostat dengan invasi perineural positif ditemukan pada 31 kasus $(29,24 \%)$ dan sebagian besar kasus dengan invasi perineural adalah negatif. 
Tabel 2. Distribusi grade group adenokarsinoma prostat berdasarkan kelompok umur

\begin{tabular}{cccccc}
\hline & \multicolumn{5}{c}{ Grade group } \\
\cline { 2 - 6 } Usia & $\mathbf{1}$ & $\mathbf{2}$ & $\mathbf{3}$ & $\mathbf{4}$ & $\mathbf{5}$ \\
& $\mathbf{f ~ ( \% )}$ & $\mathbf{f}(\%)$ & $\mathbf{f}(\%)$ & $\mathbf{f}(\%)$ & $\mathbf{f}(\%)$ \\
& & & & & \\
\hline$<51$ & & & & 1 & 1 \\
& & & & $(0,9)$ & $(0,9)$ \\
$51-60$ & 1 & 1 & 3 & 3 & 9 \\
& $(0,9)$ & $(0,9)$ & $(2,8)$ & $(2,8)$ & $(8,5)$ \\
$61-70$ & 3 & 6 & 2 & 4 & 20 \\
& $(2,8)$ & $(5,7)$ & $(1,9)$ & $(3,8)$ & $(18,9)$ \\
$71-80$ & 5 & 6 & 4 & 5 & 22 \\
& $(4,7)$ & $(5,7)$ & $(3,8)$ & $(4,7)$ & $(20,8)$ \\
$>80$ & 2 & 2 & 1 & 2 & 3 \\
& $(1,9)$ & $(1,9)$ & $(0,9)$ & $(1,9)$ & $(2,8)$ \\
\hline \multirow{2}{*}{ Total } & 11 & 15 & 10 & 15 & 55 \\
& $(10,4)$ & $(14,2)$ & $(9,4)$ & $(14,2)$ & $(51,9)$ \\
\hline
\end{tabular}

Tabel 2 menunjukkan hampir semua Gradegroup adenokarsinoma prostat paling banyak ditemukan pada kelompok umur 71-80 tahun yaitu grade-group 1 (4,7\%), grade-group 3 (3,8\%), grade group 4(4,7\%) dan grade-group 5 (20,8\%), sedangkan pada grade-group 2 hampir sama banyak antara kelompok usia 61-70 tahun dan 71-80 kasus yaitu masing-masing 6 kasus $(5,7 \%)$.

Tabel 3. Distribusi frekuensi invasi perineural berdasarkan grade-group adenokarsinoma prostat

\begin{tabular}{crcc}
\hline $\begin{array}{c}\text { Grade- } \\
\text { Group }\end{array}$ & \begin{tabular}{r} 
Invasi Perineural \\
Positif \\
\cline { 2 - 3 }$(\%)$
\end{tabular} & $\begin{array}{c}\text { Negatif } \\
\mathbf{f ( \% )}\end{array}$ & Total \\
\hline 1 & $1(0,9)$ & $10(9,4)$ & $11(10,4)$ \\
2 & $2(1,9)$ & $13(12,3)$ & $15(14,2)$ \\
3 & $4(3,8)$ & $6(5,7)$ & $10(9,4)$ \\
4 & $4(3,8)$ & $11(10,4)$ & $15(14,2)$ \\
5 & $20(18,9)$ & $35(33,0)$ & $55(51,9)$ \\
\hline & $31(29,2)$ & $75(70,8)$ & $106(100)$ \\
\hline
\end{tabular}

Tabel 3 menunjukkan kasus adenokarsinoma prostat dengan invasi perineural positif paling banyak ditemukan pada grade group 5 yaitu sebanyak 20 kasus $(18,9 \%)$.

\section{PEMBAHASAN}

\section{Karakteristik Adenokarsinoma Prostat}

Pada penelitian ini didapatkan jumlah kasus terbanyak pada kelompok usia 71-80 tahun yaitu sebanyak 42 kasus $(39,62 \%)$. Kasus paling sedikit ditemukan pada kelompok usia $<51$ tahun yaitu sebanyak 2 kasus (1,89\%). Sedikit berbeda dengan studi yang dilakukan oleh Pepe dan Pennisi yang mendapatkan kasus terbanyak pada kelompok usia 61-70 tahun (46\%) kemudian diikuti kelompok usia 71-80 tahun (36,2\%). ${ }^{10}$ Studi lain oleh Yang et al mendapatkan kasus terbanyak pada usia 65-75 tahun yaitu sebanyak 173 kasus. ${ }^{11}$

Karsinoma prostat merupakan keganasan terbanyak pada laki-laki usia tua. Angka kejadian dan kematian karsinoma prostat ini meningkat seiring peningkatan usia. Lebih $75 \%$ kasus ditemukan pada usia > 65 tahun dan hanya 1\% ditemukan pada usia < 50 tahun. $^{2}$ Studi pada laki-laki di USA menunjukkan bahwa risiko berkembangnya karsinoma prostat pada laki-laki bertambah seiiring peningkatan usia yaitu pada usia < 49 tahun risiko sekitar 0,3\% (1 dari 298 laki-laki), usia 50-59 tahun menjadi 2,3\% (1 dari 43 laki-laki), usia 60-69 tahun risiko meningkat menjadi 6,4\% (1 dari 16 laki-laki) dan laki-laki diatas 70 tahun risiko meningkat menjadi $11,2 \%$ (1 dari 9 laki-laki). ${ }^{1}$ Beberapa studi univariat menyatakan bahwa umur mempengaruhi prilaku biologis sel tumor dan angka kematian adenokarsinoma prostat. Umur muda sering dihubungkan dengan angka ketahanan hidup yang tinggi dan umur tua berhubungan dengan faktor prognostik yang buruk seperti Gleason score yang tinggi, stadium lanjut dan kadar PSA serum yang tinggi. Namun apakah usia mempengaruhi prognosis pasien masih menjadi kontroversi. ${ }^{12}$

Pada penelitian ini dilakukan reevaluasi Gleason score berdasarkan ISUP 2014/WHO 2016 kemudian dikelompokkan berdasarkan grad-group. 
Grade-group yang terbanyak ditemukan adalah grade-group 5 (Gleason score $\geq 9-10$ ) sebanyak 55 kasus $(51,89 \%)$ dan yang paling sedikit ditemukan grade group 3 (Gleason score 4+3) yaitu sebanyak 10 kasus $(9,43 \%)$. Hal ini berbeda dengan hasil studi Leapman et al yang melaporkan kasus terbanyak adalah grade-grup 1 (64\%) dan kasus paling sedikit adalah grade-group 5 (4\%). ${ }^{13}$ Studi lain oleh Offerman et al di RS Goeppingen Jerman menemukan kasus terbanyak yaitu grade-group 2 (39,9\% kasus). ${ }^{14}$ Epstein et al juga melaporkan di beberapa rumah sakit di USA kasus terbanyak yaitu grade-group 2 (36\%). ${ }^{15}$

Derajat histopatologik adenokarsinoma prostat yang paling banyak ditemukan adalah poorly differentiated (Gleason score 8-10) dengan jumlah 70 kasus $(66,04 \%)$ dan yang paling sedikit adalah well differentiated. Penelitian oleh Valdo et al di RSUP Prof. Mandou Manado juga melaporkan kasus yang banyak ditemukan adalah poorly differentiated yaitu 46,7\%. ${ }^{16}$ Studi oleh Heo et al di Korea juga mendapatkan kasus terbanyak adalah poorly diiferentiated (41\%). ${ }^{17}$ Berbeda dengan laporan Masieri et al yang menemukan kasus terbanyak adalah well differentiated $(61,1 \%)$ dan paling sedikit adalah poorly differentiated (5\%). ${ }^{18}$ Studi oleh Atti et al pada kasus adenokarsinoma prostat di RS St.Anna Italy juga melaporkan kasus terbanyak adalah well differentiated (52\%) dan paling sedikit poorly differentiated (8\%). ${ }^{8}$

Berdasarkan kepustakaan, karsinoma prostat di negara berkembang sering didiagnosis pada stadium lanjut dan gleason score yang tinggi. ${ }^{3}$ Laporan Komite Penanggulangan Kanker Nasional juga menyebutkan bahwa stadium lanjut merupakan stadium tersering pasien adenokarsinoma prostat datang pada awal berobat yaitu sebesar 59,3\%. ${ }^{19}$ Chen et al melaporkan pada studi beberapa negara di Asia, Indonesia merupakan negara yang paling banyak ditemukan kasus adenokarsinoma prostat dengan Gleason score yang tinggi (GS>7) yaitu sekitar $70 \%{ }^{3}$

Banyaknya kasus adenokarsinoma prostat dengan group-grade yang tinggi dan poorly differentiated ini kemungkinan dipengaruhi oleh berbagai faktor diantaranya ras, genetik, faktor lingkungan, sosio-ekonomi, diet dan deteksi dini (skrining). ${ }^{3}$ Beberapa studi menyebutkan salah satu faktor yang berperan yaitu bahwa belum maksimalnya pelaksanaan deteksi karsinoma prostat dengan pemeriksaan kadar PSA serum atau kurangnya akses pelayanan kesehatan untuk melakukan skrining itu sendiri sehingga pasien ditemukan sudah pada stadium lanjut. ${ }^{3} \mathrm{Hal}$ ini berbeda dengan negara maju dimana pelaksanaan skrining adenokarsinoma prostat dengan pemeriksaan PSA serum meningkat secara signifikan sehingga kasus adenokarsinoma prostat dapat terdeteksi lebih dini sehingga kasus dengan grade group tinggi ditemukan lebih sedikit dimana kasus adenokarsinoma prostat stadium lanjut menurun lebih dari $70 \%$ dari 22 per 100.000 penduduk menjadi 6,5 per 100.000 penduduk. $^{20}$

Pada penelitian ini kasus adenokarsinoma prostat dengan invasi perineural positif ditemukan pada 31 kasus (29,24\%). Studi Yang et al juga melaporkan invasi perineural sekitar $28,7 \% .{ }^{11}$ Studi Saeter et al juga melaporkan kasus invasi perineural pada adenokarsinoma prostat sebanyak $58 \%$ kasus. $^{9}$ Sesuai dengan kepustakaan invasi perineural pada karsinoma prostat terjadi sekitar $17-75 \%{ }^{7}$ Invasi perineural merupakan salah prediktor yang buruk pada karsinoma prostat karena berhubungan dengan progresi yang buruk dari adenokarsinoma prostat seperti ekstensi ekstraprostatika, metastasis ke kelenjar limfe, metastasis ke tulang dan kekambuhan yang tinggi setelah terapi. ${ }^{7}$

\section{Distribusi Frekuensi Grade Group Adenokarsinoma Prostat Berdasarkan Kelompok Usia}

Grade-group merupakan salah satu faktor prognostik histopatologik dalam menilai progresi penyakit pada adenokarsinoma prostat. Sesuai dengan kepustakaan progresivitas penyakit juga akan meningkat seiring dengan bertambahnya usia.

Pada penelitian ini tampak hampir semua Grade-group adenokarsinoma prostat paling banyak ditemukan pada kelompok umur 71-80 tahun yaitu grade-group 1 (4,7\%), grade-group 3 (3,8\%), gradegroup 4(4,7\%) dan grade-group 5 (20,8\%), sedangkan pada grade-group 2 hampir sama banyak antara kelompok usia 61-70 tahun dan 71-80 kasus yaitu masing-masing 6 kasus (5,7\%). Hasil ini menunjukkan bahwa grade-group meningkat seiiring dengan bertambahnya usia. Hal yang sama juga dilaporkan 
Athanazio et al bahwa adenokarsinoma grade-group 1 dengan usia rata-rata 58,1, grade-group 2 usia ratarata 60,4, grade-group 3 dengan usia rata-rata 61,4, grade-group 4 dengan usia rata-rata 62,1 dan gradegroup 5 dengan usia rata-rata 63,6. ${ }^{21}$ Samaratunga et al juga melaporkan rata-rata usia termuda ditemukan pada grade-group 1 yaitu 59 tahun dan usia tertua ditemukan grade-group 5 yaitu 64 tahun. ${ }^{22}$

Suatu studi otopsi di USA melaporkan bahwa pada laki-laki usia > 70 tahun banyak ditemukan dengan karsinoma prostat yang berukuran besar dan Gleason score yang tinggi. Ada bermacam-macam hipotesis mengapa tingginya insiden karsinoma prostat dengan gleason score tinggi pada usia tua, salah satunya adalah kerusakan respon imun pada usia tua yang menurunkan resistensi host sampai perkembangan kearah keganasan, ditambah lagi adanya perubahaan epigenetik dan akumulasi paparan karsinogen yang menghasilkan abnormalitas DNA. ${ }^{23}$

\section{Distribusi Frekuensi Invasi Perineural Berdasarkan Grade Group Adenokarsinoma Prostat}

Pada penelitian ini kasus invasi perineural paling banyak ditemukan pada grade-group 5 yaitu sekitar 20 kasus (18,9\%) dan paling sedikit pada grade group 1 (0,9\%). Hal yang sama juga dilaporkan oleh Saeter et al (57\%) dimana kasus invasi perineural paling banyak ditemukan pada grade-group 4 dan 5 (57\%) dan paling sedikit ditemukan pada grade- group 1 (4\%). ${ }^{9}$ Pada penelitian ini dapat terlihat invasi perineural berhubungan dengan karsinoma prostat stadium lanjut dimana jumlah kasus dengan invasi perineural paling banyak ditemukan pada grade-group yang tinggi. Sesuai kepustakaan invasi perineural berhubungan dengan progresi buruk dari adenokarsinoma seperti ekstensi ekstraprostatika, metastasis kelenjar getah bening dan tulang. ${ }^{7,9}$ Studi oleh Gurumurthy et al melaporkan 88,3 \% kasus adenokarsinoma prostat dengan metastasis tulang ditemukan dengan invasi perineural. ${ }^{24}$

Pada invasi perineural terdapat neural paracrine factor yang berhubungan dengan inhibisi apoptosis dan meningkatnya proliferasi sel-sel tumor disekitar saraf. Interaksi antara saraf, sel epitel tumor dan stroma menghasilkan kompleks sinyal yang menyokong perkembangan tumor. ${ }^{20}$

Laporan tentang invasi perineural berbedabeda pada berbagai studi. Perbedaan hasil yang didapatkan dipengaruhi oleh beberapa faktor diantaranya perbedaan dalam sampel. Pada penelitian ini sebagian besar sampel berasal dari spesimen TURP yaitu sebanyak 84 kasus dan hanya 22 kasus diambil dari prostatektomi. Zareba et al melaporkan terdapat perbedaan prevalensi invasi perineural pada spesimen TURP dan prostatektomi. Pada TURP tumor diambil pada zona transisi, sedangkan pada prostatektomi tumor diambil sebagian besar pada zona perifer. ${ }^{25}$ Secara anatomi zona perifer merupakan zona terbesar pada kelenjar prostat yaitu sekitar $70 \%$ dan sebagian besar karsinoma terjadi pada zona ini, sedangkan zona perifer hanya sekitar $10-20 \%$ dari kelenjar prostat. Kepustakaan menyebutkan zona perifer mendapatkan distribusi saraf yang lebih banyak dibandingkan zona transisi. ${ }^{25}$

\section{SIMPULAN}

Adenokarsinoma prostat terbanyak ditemukan pada kelompok usia $70-80$ tahun $(39,62 \%)$ dan paling sedikit ditemukan pada usia $<51$ tahun, grade-group adenokarsinoma prostat yang paling banyak ditemukan yaitu grade-group 5 (Gleason score $\geq 9-10$ ) yaitu $51,89 \%$ kasus, derajat histopatologis yang paling banyak dijumpai adalah poorly differentiated (Gleason score 8-10) yaitu 66,04\% dan paling sedikit yaitu well differentiated (Gleason score $\leq 6$ ) yaitu 10, $38 \%$.sedangkan invasi perineural terjadi pada $29,24 \%$ kasus. Hampir semua grade group adenokarsinoma prostat terjaddi pada kelompok umur 71-80 tahun. Invasi perineural paling banyak ditemukan pada grade group 5.

\section{SARAN}

Dibutuhkan penelitian lebih lanjut mengenai faktor-faktor prognostik lain pada adenokarsinoma prostat terkait dengan prognosis dan terapi. 


\section{DAFTAR PUSTAKA}

1. Bashir NM. Epidemiology of prostate cancer. Asian Pasific Journal of Cancer Prevention. 2015;16: 1-4.

2. Humprey PA, Amin MB, Berney DM, Billis A, Cao D, Cheng $\mathrm{L}$, et al. Acinar adenocarcinoma prostate. Dalam: Moch H, Humprey PA, Ulbright TM, Reuter VM, editor (penyunting). WHO classification of tumours of the urinary system and male genital organs. Edisi ke-4. France. IARC; 2016.hIm.136-62

3. Chen R, Ren S, Yiu MK, Fai NC, Cheng WS, Lan $\mathrm{LH}$, et al. Prostate cancer in Asia: collaborative report. Asian Journal of Urology. 2014;(1):15-29.

4. Badan Registrasi Kanker Perhimpunan Dokter Spesialis Patologi Indonesia. Kanker di Indonesia tahun 2014: data histopatologik. Jakarta: Direktorat Jendral Pelayanan Medik Kementerian Kesehatan RI, Yayasan Kanker Indonesia. 2018.

5. Paner GP, Smith SC, Ahmadi HA. Prostate gland and seminal vesicle. Dalam: Amin MB, Tickoo SK, editor (penyunting). Diagnostic Pathology Genitourinary. Edisi ke-2. Philadelpia: Elsevier; 2016. hlm.536-14.

6. Gordetsky J, Epstein J. Grading of prostatic adenocarcinoma :current state and prognostic implication. Diagnostic Pathology. Biomed Central. 2016;11(25): 1-8.

7. Meng Y, Liao YB, Xu P, Wei WR, Wang J. Perineural invasion is an independent predictor of biochemical recurrent of prostate cancer after local treatment: a meta-analysis. Int J Clin Exp Med. 2015; 8(8):13267-74.

8. Atti LD. Prognostic significance of perineural invasion in patients who underwent radical prostatectomy for localized prostate. Journal of Balkan Union of Oncology. 2016; 21(5):1219-23.

9. Saeter T, Bogaard M, Vlatkovic L, Waaler G, Servoll E, Nesland JM, et al. The relationship between perineural invasion, tumor grade, reactive stroma, and prostate cancer-spesific mortality: a clinicopathology study on population-based cohort. The Prostate. 2015;76(2): 207-14.

10. Pepe P, Pennisi M. Gleason score stratification according to age at diagnosis in 1028 men. Contemporary Oncology. 2015;19(6): 471-3.

11. Yang R, Cao K, Han T, Zhang FY, Zhang GT, Xu LF, et al. Perineural invasion status, Gleason score, and number of positif cores in biopsy pathology are predictors of positive surgical margin following laparoscopic radical prostatectomy. Asian Journal of Andrology. 2017;(19): 468-72.

12. Cruz JS, Passeroti CC, Reis ST, Guariero ME, Campos OD, Leite KR, et al. Is age an independent factor for prostate cancer?a paired analysis. Current Urology. 2015;(9);183-7.

13. Leapman MS, Cowan JE, Simko J, Roberge G, Stohr BA, Carroll PR, et al. Application of a prognostic Gleason grade grouping system to access distant prostate cancer outcomes. European Urology. 2017;(71): 750-9.

14. Offerman A, Hohenstainer S, Kuemper C, Idel JR, Schneider F, Becker F, et al. Prognostic value of new prostate cancer international society of urological pathology grade group. Frontier in Medicine. 2017;157(4):1-7.

15. Epstein JI, Zelefsky MJ, Sjoberg DD, Nelson JB, Egevad L, Galluzi CM, et al. A contemporary prostate cancer grading system: a validated alternative to the gleason score. European Association of Urology. Elsevier. 2016;69(3):428-35.

16. Valdo $R$, Alwin M, Ferdinand T. Profil penderita kanker prostat di RSUP Prof. Dr. R. D Kandou Manado periode tahun 2013. Jurnal e-Clinic. 2015; $4(2): 1-8$.

17. Heo JE, Ahn KH, Kim J, Chung BH, Lee KS. Changes in clinical characteristic of patients with an initial diagnosis of prostate cancer in Korea: 10year trends reported by a tertiary center. Journal Korean Medical Science. 2018;33(6):1-9.

18. Masieri L, Laciotti M, Nesi G, Lanzi F, Tosi N. Prognostic role of perineural invasion in 239 consecutive patients with pathologically prganconfined prostate cancer. Urologia Internationalis. 2010;(85): 396-400.

19. Komite Penanggulangan Kanker Nasional. Panduan penatalaksanaan kanker prostat. Kementerian Kesehatan Republik Indonesia. 2015.

20. Moul JW. Population cancer for prostate cancer and early detection. Dalam: Mydlo JH, Godec CJ, editor (penyunting). Prostate cancer science and clinical. Edisi ke-2..Amsterdam. Elsevier; 2016.hlm. 8-17.

21. Athanazhio D, Gotto G, Budgell MS, Yilmas A, 
Trpkov K. Global Gleason grade group in prostate cancer: concordance in biopsy and radical prostatectomy grades and predictor of Upgrades and downgrades. Histopatology. John Willey and Sons. 2017.hlm.1-9.

22. Samaratunga $H$, Delahunt $B$, Gianduzzo $T$, Coughlin G, Duffy D, Levevre I, et al. The prognostic significance of the 2014 international society of urological pathology (ISUP) grading system for prostate cancer. Anatomical Pathology. 2015;47(6): 515-9.
23. Kukreja JB, Messing EM. Prostat cancer in erderly. Dalam: Mydlo JH, Godec CJ, editor (penyunting). Prostate cancer science and clinical. Edisi ke-2. Amsterdam. Elsevier; 2016.hlm.66-75.

24. Gurumurthy D, Maggad R, Patel S. Prostate carcinoma: correlation of histopathology with serum prostate spesific antigen. Science Journal of Clinical Medicine. 2015; 4(4-1):1-5.

25. Zareba P, Flavin R, Isikbay M, Rider JR, Gerge TA, Finn $S$, et al. Perineural invasion and risk of lethal prostate cancer. Cancer Epidemiology Biomarker. 2017:26(5): 719-26. 